\title{
Analisis Laporan Kepolisian No: B.210 /VIII/2018/JAMBI/SPKT.C Mengenai Alasan Dihentikannya Penyidikan Perkara Perkosaan Anak
}

\author{
M. Rudi Hartono, Lilis Winantri \\ Fakultas Hukum Universitas Batanghari \\ Email: mrudihartono700@gmail.com, liliswinantri@gmail.com
}

\begin{abstract}
Abstrak. Polisi adalah bagian dari sistem peradilan pidana sebagaimana terdapat dalam ketentuan Hukum Acara Pidana dan undang-undang lainnya, sistem ini memiliki kekuasaan untuk melakukan penyelidikan dan penyidikan atas kejahatan. Kewenangan penyidikan diberlakukan terhadap pelaku dalam tindak pidana atau kewenangan penyidikan ditegakkan, dan kasus telah dikoordinasikan dengan penuntut umum sejak gelombang pertama penyidikan. Kesalahan yang sama. Perkara pidana yang diteliti pada tulisan ini didasarkan pada data-data penelitian penulis pada Direktorat Reserse Kriminal Umum Subdit IV Polda Jambi. Adalah melibatkan Surat Laporan Kepolisian No: LP/B/210/VIII/2018/Jambi/SPKT “C” yang berisi tentang tindak pidana dugaan perkosaan atau persetubuhan dengan anak di bawah umur. Pelaku diancam dengan pasal 81 dan 82 Undang-Undang Republik Indonesia Nomor 35 Tahun 2014 (Revisi Undang - Undang Perlindungan Anak Republik Indonesia Nomor 23 Tahun 2002). Penyidik mungkin masih menemui kendala dalam penyidikan tindak pidana pemerkosaan tersangka atau berhubungan seks dengan anak di bawah umur. Tidak semua kasus pidana pemerkosaan atau persetubuhan di bawah umur yang ditangani di tingkat penyidikan dapat dilimpahkan ke pengadilan oleh kejaksaan sebagai penuntut umum dalam proses penyidikan lebih lanjut. Dalam hal ini, penyidik pada Subdit IV Direktorat Reserse Kriminal Umum (Ditreskrimum) Kepolisian Daerah Jambi juga memiliki kewenangan untuk tidak melanjutkan proses penyidikan atau menghentikan penyidikan (SP3) dalam perkara pidana ini berdasarkan pertimbangan-pertimbangan perkara pidana yang diproses bukan merupakan suatu perbuatan pidana, kurangnya alat bukti ataupun pertimbangan hukum lainnya. Tujuan dari penelitian ini adalah: Pertama-tama saya ingin mengetahui dan menganalisis bagaimana penyidik menangani kasus pelaku pemerkosaan anak (Penyidikan kasus, nomor laporan polisi: B. 2018 / Jambi / SPKT “C”).Kedua, ingin mengetahui apa alasan penghentian penyidikan terhadap pemerkosaan anak adalah (Laporan Polisi Nomor: B.210 / VIII/2018 / Jambi / SPKT "C"). Metode Penelitian yang digunakan dalam penelitian ini adalah Sosio Legal Research, yakni mempelajari praktik hukum atau peraturan perundang-undangan yang berlaku dalam kehidupan sosial masyarakat. Spesifikasi penelitian deskriptif, yaitu mendeskripsikan dan menganalisis suatu peristiwa hukum yang telah terjadi dengan cara mendeskripsikan peristiwa yang ada.
\end{abstract}

Kata kunci: Police, Investigation, and Rape

\begin{abstract}
The police are part of the criminal justice system as contained in the provisions of the Criminal Procedure Code and other laws, this system has the power to conduct investigations and investigations of crimes. The investigative authority is applied to the perpetrator in a criminal act or the investigative authority is enforced, and the case has been coordinated with the public prosecutor since the first wave of investigation. The same mistake. The criminal cases studied in this paper are based on the author's research data at the Directorate of General Criminal Investigation, Sub-Directorate IV of the Jambi Regional Police. This involves the Police Report Letter No: LP/B/210/VIII/2018/Jambi/SPKT "C" which contains the alleged crime of rape or intercourse with a minor. Perpetrators are threatened with articles 81 and 82 of the Law of the Republic of Indonesia Number 35 of 2014 (Revised Law on Child Protection of the Republic of Indonesia Number 23 of 2002). Investigators may still encounter obstacles in investigating criminal acts of raping a suspect or having sex with a minor. Not all criminal cases of rape or sexual intercourse of minors that are handled at the investigation level can be transferred to the court by the prosecutor as a public prosecutor in the process of further investigation. In this case, investigators at Sub-Directorate IV of the Directorate of General Criminal Investigation (Ditreskrimum) of the Jambi Regional Police also have the authority to not continue the investigation process or stop the investigation (SP3) in this criminal case based on considerations that the criminal case processed is not a criminal act, lack of evidence or other legal considerations. The objectives of this study are: First of all, I want to know and analyze how investigators handle cases of child rape perpetrators (case investigation, police report number: B. 2018 / Jambi / SPKT "C"). Child rape is (Police Report Number: B.210 / VIII/2018 / Jambi / SPKT "C"). The research method used in this research is Socio Legal Research, which is studying the practice of law or legislation that applies in the social life of the community. Descriptive research specifications, namely describing and analyzing a legal event that has occurred by describing the existing events.
\end{abstract}

Keyword: Police, Investigation, and Rape

\section{PENDAHULUAN}

Dalam proses penyidikan, guna mencari barang bukti penyidik diberikan kewenangan untuk melakukan tindakan tertentu guna menyelesaikan penyidikan dan siap mengeluarkan Berita Acara Pemeriksaan (BAP) kepada penuntut umum. Tentu saja kewenangan penyelidik akan disesuaikan dengan keadaan tertentu, termasuk tindakan wajib lainnya seperti penangkapan, penangkapan, penggeledahan, penyitaan, dan pemeriksaan surat di tempat 
kejadian. Dalam menangani setiap kasus kejahatan, tindakan ini akan digunakan semaksimal mungkin untuk memberikan bukti yang dianggap bermanfaat bagi penuntutan dan persidangan kasus tersebut.

Ketentuan mengenai Penyidik diatur dalam Pasal 1 Kitab Undang-undang Hukum Acara Pidana (KUHAP). Menurut Andi Hamzah dan Irdan Dahlan, Penyidik adalah "bagian yang tidak dapat dipisahkan dari tugas penyidikan, karena ia merupakan salah satu metode dari penyidikan, untuk mengumpulkan fakta dan bukti-bukti berkaitan dengan kegiatan yang terjadi untuk menentukan tersangkanya. ${ }^{1}$

Sedangkan menurut R. Soesilo menyatakan bahwa "Penyidik adalah pejabat Kepolisian negara Republik Indonesia dan pejabat pegawai negeri sipil tertentu yang diberi wewenang khusus oleh Undang-Undang untuk melakukan penyidikan. ${ }^{2}$

Melalui undang-undang ini, Polri dalam rangka pelaksanaan tugas Polri diberikan kewenangan umum untuk melakukan tindakan pengenalan identitas seseorang, yaitu mengambil sidik jari dan identitas lainnya serta memotret seseorang. ${ }^{3}$

Selanjutnya menurut M. Yahya Harahap menyatakan bahwa:

\begin{abstract}
"Penyidik ialah orang yang melakukan penyelidikan, yang berarti serangkaian tindakan mencari dan menemukan sesuatu keadaan atau peristiwa yang berhubungan dengan kejahatan dan atau pelanggaran yang diduga sebagai perbuatan tindak pidana". 4
\end{abstract}

Istilah penyidik dan penyidikan berbeda satu sama lain, jika penyidik ditujukan kepada orang (orang) (KUHAP) yang melakukan penyidikan sesuai dengan kewenangan yang diberikan oleh pembuat undang-undang (KUHAP), maka penyidikan menjadi lebih banyak berkaitan dengan subyek ( tindakan). Saat melakukan penyelidikan dan penyidikan kegiatan, agar perilaku tersebut dapat diketahui dengan jelas dan pelakunya dapat diketahui.

Kenyataannya, polisi menilai penanganan penyidik terhadap kasus pidana merupakan tugas berat bagi polisi. Dalam berinteraksi dengan masyarakat, polisi harus menghadapi berbagai perilaku pribadi. Setiap orang memiliki tingkat kepatuhan yang berbeda-beda. Terkadang, seorang polisi tidak cukup menunjukkan identitas polisinya, seperti mengenakan seragam polisi atau menunjukkan lencana polisi.

Perbuatan pidana yang diteliti pada tulisan ini adalah mengenai tindakan perkosaan yang dilakukan yakni identitas diri pelaku bernama dengan inisial nama RP yang dilaporkan oleh korban dengan inisila nam MW. Tindak Pidana Perkosaan tercatat dala Laporan Polisi No : LP/B-210/VIII/2018/Jambi/SPKT"C” pada tanggal 6 agustus 2018.

Peristiwa kasus perkosaan ini dilakukan sekitar april tahun 2018 dengan sikorban berumur 16 tahun dan Sipelaku berumur 21 tahun dan mereka adalah pasangan muda mudi yang sedang terikat dalam hubungan pacar dimana Korban disaat menjadi pacar dari si pelaku sering berbuat atau ber hubungan badan seperti sepasang suami isteri pada rumah Pelaku. Perkiraan pada bulan juni tahun 2018 sebelum lebaran idul fitri 1439 Hijriah, korban dan sipelaku tidak lagi menjalin hubungan pacaran.zakan tetapi meskipun telah tidak terikat hubungan pacaran, diawal bulan juli 2018 pelaku dan korban ternyata masih berbuat hubungan sebagaimana suami isteri pada kosan kawan korban yang berada dibelakang SMKN 1 kota Jambi. Perkiraan diakhir Juli 2018 si wanita merasa mual-mual pada perutnya kemudian korban mengecek di Dr.Edwin,Sp.OG dan diketahui dari hasil pemeriksaan, ternyata sikorban telah positif mengandung. Korban memberitahukan kepada pelaku dan meminta pertanggungjawaban kepada pelaku, akan tetapi hal tersebut ditolak dan tidak diakui oleh pelaku. Atas kejadian tersebut, korban mengalami hamil 4 (empat) bulan dan melaporkan kejadian ini ke Ditreskrimum Kepolisian Daerah Jambi untuk ditindak lanjuti.

Oleh karena tindakan yang telah dilakukannya, maka sipelaku dikenakan ancaman Pasal 81 dan Pasal 82 UU No. 35 Tahun 2014 tentang perubahan UU No. 23 Tahun 2002 tentang Perlindungan Anak. Dengan ancaman pidana penjara paling singkat 5 tahun dan paling lama 15 (lima belas) tahun dan denda paling banyak Rp.5.000.000.000,(Lima milyar rupiah).

Tndak pidana pemerkosaan atau hubungan seksual kemudian ditangani oleh penyidik Subdit IV Ditreskrimum Polda Jambi. Selidiki dugaan pemerkosaan anak di bawah umur Kumpulkan bukti yang diperlukan Penyidik akan diberi wewenang untuk mengambil langkah-langkah tertentu Selesaikan penyelidikan dan siap untuk menunjukkan petugas polisi kepada jaksa.

${ }^{1}$ Andi Hamzah dan Irdan Dahlan, Perbandingan KUHP dengan HIR dan Komentarnya, Ghalia Indonesia : Jakarta, 2009. Hal.25.

${ }^{2}$ R. Soesilo, Hukum Acara Pidana (Prosedur Penyelesaian Perkara Pidana Menurut KUHAP bagi Penegak Hukum), Politea : Bogor, 2005. Hal.26,

${ }^{3}$ Momo Kelana, Konsep-konsep Hukum Kepolisian Indonesia, Jakarta: PTIK Press, 2007.., hal.91

${ }^{4}$ M. Yahya Harahap, Pembahasan, Permasalahan dan Penerapan KUHAP, Garuda Metropolitan Press : Jakarta, 2006. Hal.99. 
Dalam penyidikan tindak pidana perkosaan harus diperhatikan, yaitu tugas penyidikan polisi dalam menyusun BAP. Semuanya ini diperlukan agar tidak terjadi kesalahan sekecil apapun yang berdampak negatif dan menghindarkan tersangka dari segala tuntutan pidana atau penangguhan penuntutan oleh jaksa.

Diwaktu seorang penyidikk memulai melaksanakan rangkaian proses lidik, memiliki kewajiban untuk memberitahu segala hal dimulai proses penyidikan tersebut pada Jaksa. Namun masalah tugas kewenangan memberitahu tersebut bukan hanya dalam proses permulaan proses penyidikan, akan tetapi juga dalam proses penghentian penyidikan. Oleh karena itu, maka dalam tiap proses sidik yang dilaksanakan oleh penyidik resmi wajib diterrbitkan Surat Perintah Penghentian Penyidikan atau dikenal dengan istilah SP3. ${ }^{5}$

Ditinjau dari sudut hukum, maka tiap Penyidik didalam melaksanakan proses Penyidikan pada kasus tindak pidana dalam hal ini juga megenai proses penyidikan kasus tindak pidana pemerkosaan ataupun pencabulan terhadap seorang anak yang masih dibawah umur sebagaimana tertuang didalam tulisan ini, diharuskan sedapat mungkin dilakukan proses penyidikan pada kasus tindak pidana yang baik dan benar, untuk menciptakan ditegakannya hukum yang adil dan memuat rasa kepastian hukum terutama bagi diri sitersangka bisa tercapai dan menciptakan kepastian hukum pada public secara umumnya.

Namun pada dasarnya didalam pelaksanaan proses penyidikan kasus tindak pidana pemerkosaan atau pencabulan terhadap anak yang masih dibawah umur bagi diri sitersangka, tidak tertutup adanya suatu Kemungkinan adanya kendala-kendala yang ditemukan oleh Penyidik.

Hal ini dikarenakan bahwa tidak semua kasus tindak pidana pemerkosaan atau pencabulan anak dibawah umur yang telah diproses dalam pemeriksaan di tingkat penyidikan dapat diteruskan kepada proses pemeriksaan lebih lanjut oleh Jaksa selaku penuntut umum sampai kepada proses sidang di Pengadilan. Dalam hal ini, penyidik pada Subdit IV ditreskrimum Kepolisian Daerah Jambi juga memiliki kewenangan untuk tidak melanjutkan proses penyidikan atau menghentikan penyidikan (SP3) dalam perkara pidana ini berdasarkan pertimbangan-pertimbangan perkara pidana yang diproses bukan merupakan suatu perbuatan pidana, kurangnya alat bukti ataupun pertimbangan hukum lainnya.

\section{Rumusan Masalah}

Guna menghindari agar tulisan dalam penelitian jurnal ini tidak jauh dari rumusan masalah yang diinginkan, untuk itu perlu diberikan pembatasan didalam permasalahan yang dikaji yakni:

1. Bagaimanakah Penyidik menangani tindak pidana pemerkosaan anak dalam laporan Polisi No: B.210/VIII/2018/Jambi/SPKT"C"?

2. Apa dasar alasan didalam menghentikan proses sidik pada perkara tindak pidana pemerrkosaan anak dalam laporan Polisi No: B.210/VIII/2018/Jambi/SPKT"C”)?

\section{METODE}

\section{Tipe Penelitian}

Pendekatan penelitian yang digunakan dalam penelitian ini secara Sosio Legal Research, yakni penelitian dengan melihat praktek hukum atau peraturan undang-undang yang berlaku dalam kehidupan sosial masyarakat. ${ }^{6}$ Dalam hal ini, mengetahui dan memahami bagaimanakah hukum diimplementasikan tentang penghentian penyidikan kasus pemerkosaan anak dalam laporan Polisi No:B.210/VIII/2018/Jambi/SPKT"C").

\section{Spesifikasi Penelitian}

Spesifikasi Penelitian memiliki sifat deskriptive analysis, yakni mendeskripsikan dan menganalisis adanya fenomena-fenomena hukum yang ada dan menjelaskan peristiwa-peristiwa yang terjadi, ${ }^{7}$ didalam kaitan pada penelitian tentang alasan penghentian penyidkan pada perkara tindak pidana pemerkosaan dalam laporan polisi No: B.210/VIII/2018/Jambi/SPKT"C").

\section{Sumber Data}

Demi memperoleh data-data yang dibutuhkan didalam menyusun penulisan ini, didapatkan dari ;

a. Data Primer

Data ini didapatkan dari adanya penelitian pustaka (Library Research) dari adanya peraturan undang-undang yakni KUHAP, UU No 2 Tahun 2002 tentang Kepolisian, UU No 35 Tahun 2014 tentang perubahan atas UU No.23 Tahun 2002 tentang Perlindungan Anak, serta Kamus hukum dan buku-buku teks lainnya.

b. Data Skunder

Data ini penulis peroeleh dari data penelitian dilapangan (Field Research) yaitu dengan dilakukannya studi dokumentasi pada data laporan Kepolisian No:B.210/VIII/2018/Jambi/SPKT"C". Tujuan dilakukannya

${ }^{5}$ Lilik Mulyadi, 2007. Hukum Acara Pidana Normatif, Teoritis, Praktik dan Permasalahannya, PT.Alumni. Bandung. Hal.54

${ }^{6}$ J. Supranto, Metode Penelitian Hukum dan Statistik, cet. Ke-1, (Jakarta:Rineka Cipta, 2003), hal.21.

${ }^{7}$ Ibid., 
penngumpulan data-data skunder yakni untuk memproleh data-data yang lebih nyata serta memiliki keterkaitan yang erat pada penelitian yang dilakukan.

\section{Analisis Data}

Data primer yang penulis peroleh dalam pencarian, pencarian lapangan, kemudian penulis mengumpulkannya kemudian diagregasi, diolah dan diklasifikasikan menjadi beberapa bagian, untuk diolah dan dianalisis. Analisis data yang penulis gunakan dalam penelitian ini adalah analisis kualitatif, khusus analisis dengan tes semua data hasil diantaranya diberikan oleh responden dari studi lapangan, di Subdit IV Direktorat Reserse Kriminal Umum Polda Jambi, kemudian disajikan sebagai dari formulir dari yang dijelaskan dalam disajikan dalam pembahasan.

\section{HASIL DAN PEMBAHASAN}

\section{Penyidik Dalam Menangani perkara tindak pidana Pemerkosaan dalam Laporan Polisi No:B.210/VIII/2018/Jambi/SPKT"C".}

Didalam melaksanakan penyidikan, untuk memperoleh bukti untuk itu penyidik diberi wenang-wenang dalam melaksanakan upaya-upaya tertentu, hingga diupaya bisa menyelesaikan penyidikan dan menyerahkan BAP pada Jaksa. Kewenangan dimiliki oleh penyidik ini disesuaikan dengan kasus yang sedang dihadapi, termasuk melaksanakan tindakan ditempat kejadian perkara hingga melakukan tindakan lain yang memiliki sifat memaksa, diantaranya melaksanakan tindakan Penangkapan, Penahanan, Penggeledahan, Penyitaan, serta Pemeriksaan Surat. Sedapat mungkin upaya itu akan dilakukan didalam menghadapi tiap perkara yang sedang ditangani, untuk bisa terpenuhi proses pembuktian yang dianggap diperlukan, demi keperluan penuntutan serta proses sidang.

Didalam prakteknya seringkali terjadi penyidikan yang berlarut tanpa batas waktu penyelesaian. Mengenai proses Sidik apa dihentikan ataupun dilmpahkan kepada jaksa. Guna mengatasi masalah ini perlu adanya rumusanrumusan yang memiliki kejelasan tentang perkembangan proses sidiki, seperti :

1. Penyidik memberitahukan mengenai hasil perkembangan proses sidik pada Jaksa, dan

2. Jaksa meminta keterangan pada Penyidik mengenai sejauh mana dilakukannya proses penyidikan yang dilakukan. ${ }^{8}$

Didalam penangangan perkara tindak pidana perkosaan pada anak yang dilakukan oleh Pelaku, aparat Kepolisian dalam hal ini Penyidik beranjak dari adanya Laporan Kepolisian No: B.210/VIII/ 2018 /Jambi/SPKT"C", memuat adanya rangkaian peristiwa tindak pidana perkosaan yang diperbuat oleh pelaku dicantum didalam data singkat peristiwa laporan kepolisian sebagaimana berikut ini ;

Bermula pada bulan April 2018 korban dan pelaku menjalin hubungan pacaran dimana pada waktu itu seringkali melaksanakan hubungan suami isteri dirumah pelaku ataupun di TKP. Sekira dibulan Juni 2018 sebelum Hari Raya Idul Fitri 1439 Hijriah, korban dan pelaku berpisah atau tidak lagi berpacaran. Akan tetapi meski sudah tidak berpacaran, sekira dibulan juli 2018 korban dan pelaku masih melaksanakan hubungan suami isteri dirumah kost kediamana kawan pelaku di wilayah SMKN 1 Jambi.

Perkiraan diakhir bulan juli 2018, korban merasa mual pada perutnya dan korban memeriksakan kandungannya pada praktek dokter Erwin dan didapat hasil pemeriksaan yang dilakukan oleh dokter, ternyata korban positif hamil. Korban selanjutnya menginformasikan berita hasil pemeriksaan kandungan diri korban pada pelaku. Korban berniat untuk memperoleh tanggungjawab dari pelaku, melainkan pelaku menolak dan tidak ingin mengaku atas perbuatan hubungan suami isteri yang seringkali dilakukan pelaku dengan korban hingga berakibat korban telah mengandung 4 (empat) bulan. Atas peristiwa ini, akhirnya korban melapor peristiwa yang dialamin pada Kepolisian Daerah Jambi untuk dapat diproses lebih lanjut.

Dari data berkas laporan kolisian itu maka Kepala Kepolisian Daerah Jambi, dalam hal ini Pimpinan penyidik memerintahkan dikeluarkannya Surat Perintah Tugas No : SP.Gas/484/VIII/ Res.1.24/2018/2018/Ditreskrimum untuk diberikan pada 15 (lima belas) orang penyidik polisi diantaranya sebagai berikut :

1. AKBP. Herry Manurung,S.T : selaku Penyidik;

2. Kompol Yanepi,SH : selaku Penyidik;

3. Iptu Suhartono,SH : selaku Penyidik;

4. Bripka Supriyadi : selaku Penyidik Pembantu;

5. Bripka Agusriani,SH : selaku Penyidik Pembantu;

6. Brigpol Rahmat Hidayat : selaku Penyidik Pembantu;

7. Brigpol Neda Suhendar : selaku Penyidik Pembantu;

8. Brigpol Muslim Ansori : selaku Penyidik Pembantu;

9. Bripda Yusmaleni : selaku Penyidik Pembantu;

\footnotetext{
${ }^{8}$ Husein Harun, M. 2001. Penyidikan dan Penuntutan Dalam Proses Pidana, Rineka Cipta Jakarta.hal. 29.
} 
10.Bripda M.Dika Kaswara : selaku Penyidik Pembantu;

11.Bripda Tengku Dwi Purnama : selaku Penyidik Pembantu;

12.Bripda Iis Gustharica : selaku Penyidik Pembantu;

13.Bripda Metha Marsita : selaku Penyidik Pembantu;

14.Bripda Maya Anggela : selaku Penyidik Pembantu;

15.Bripda Selyta : selaku Penyidik Pembantu;

Kesemua nama-nama diatas diberikan tugas:

1. Melakukan tugas penyidikan terhadap perkara tindak pidana persetubuhan anak dibawah umur sebagaimana dimaksud dalam Pasal 82 Undang-Undang Republik Indonesia Nomor 35 Tahun 2014 Tentang Perubahan Atas Undang-Undang Republik Indonesia Nomor 23 Tahun 2002 Tentang Perlindungan Anak;

2. Surat Perintah ini berlaku sejak tanggal 21 Agustus 2018;

3. Membuat Rencana Penyidikan

4. Melaksanakan perintah ini dengan penuh rasa tanggung jawab dan melaporkan hasilnya kepada pimpinan.

Selain mengeluarkan Surat Perintah Tugas, Direktur Reskrimum Kepolisian Daerah Jambi selaku pimpinan juga mengeluarkan Surat Perintah Penyelidikan Nomor: SP.Lidik/485/VIII/Res.1.24/2018/Ditreskrimum kepada 15 (lima belas) Anggota Ditreskrimum Kepolisian Daerah Jambi yang diberikan tugas. Surat perintah penyelidikan ini dikeluarkan dengan pertimbangan bahwa untuk kepentingan penyelidikan tindak pidana, maka dipandang perlu mengeluarkan surat perintah penyelidikan.

Selanjutnya, penyidik Ditreskrimum Polda Jambi melaksanakan panggilan pada pelaku demi dilakukannya proses pemeriksaan. Terhadap surat panggilan dari Penyidik tersebut, pelaku mengabaikan dan tidak segera menghadap pada penyidik. Untuk itu p enyidik Ditreskrimum Polda Jambi langsung melakukan pencarian keberadaan dimana pelaku untuk kemudian dilakukan tindakan penangkapan terhadap sipelaku. Selanjuntnya pelaku dibawa ke Polda Jambi, dan selanjutnya pelaku dilakukan pemeriksaan sebagai tersangka yang didasarkan bukti yang diberikan oleh korban dan terhadap diri pelaku maka penyidik melakukan penahanan demi proses pemeriksaan lanjutan.

Upaya penahanan yang dilaksanakan penyidik Ditreskrimum Polda Jambi pada pelaku disesuaikan pada ketentuan yang diatur didalam pasal 21 Ayat (1) KUHAP sebagaimana berikut :

a. Diduga keras melaksanakan kejahatan berdasarkan bukti yang cukup;

b. Dalam hal adanya keadaan yang menimbulkan kekhawatiran bahwa tersangka atau terdakwa akan kabur, melakukan perusakan, atau barang bukti dihilangkan; dan

c. Mengulangi kejahatannya. ${ }^{9}$

Selanjutnya Penyidik menahanan pelaku, dan melaksanakan penyusunan Berkas Acara Pemeriksaan perkara (BAP) pelaku dan penyidik melengkapi semua berkas untuk dilakukan proses limpah semua berkas yang ada diberikan pada Jaksa. Penyidik Ditreskrimum Polda Jambi juga menyerahkan surat pemberitahuan perkembangan hasil Penyidikan No: B/484/VIII/Res.1.24/2018/Ditreskrimum pada Pelapor.

Berkas surat diberikan Penyidik untuk diberitahukan bahwa Penyidik sudah memproses laporan polisi No: LP/B.210/VIII/2018/Jambi/SPKT"C" serta sudah melaksanakan proses saksi yang diperiksa dan memperoleh alat bukti yang berkaitan pada perkara yang diduga sebagai tindak pidana pemerkosaan ataupun persetubuhan pada anak di bawah umur.

Sebelum BAP dipandang sudah cukup dan telah lengkap guna diproses kepelimpahan pada Penuntunt umum, maka dari keluarga korban sudah terlebih dahulu melaksanakan upaya hukum nonpenal yakni dengan dilakukannya tindakan perdamaian antara diri pelaku dengan korban dan keluarganya.

\section{Dasar Alasan Penyidik Menghentikan Penyidikan Perkara Tndak Pidana Pemerkosaan Anak Dalam Laporan Polisi No : B.210/VIII/ 2018/Jambi/SPKT"C"}

Permasalahan tindak perkosaan anak khususnya wanita menunjukan adanya keberadaan wanita yang lebih rentan pada kepentingan biologi kaum lelaki. Hakekat seks menempatkan wanita sebagai obyek bilogi laki-laki berakibat terhadap adanya harkat perempuan hingga ia sering berhadapanan dengan tindakan kekerasan, paksaan, dan siksaan fisikis dan pisikis. Untuk itu, maka pemerkosaan tidak hanya menunjukan keberadaan perempuan sebagai obyek sexsual melainkan jadi obyek biologis laki-laki. 
Adanya hal mendasar sebagai alasan penyidik Ditreskrimum Polda Jambi untuk melaksanakan tindakan penghentian penyidikan pada perkara tindak pidana pemerkosaan anak sebagaimana tertuang didalam laporan polisi No: B.210/VIII/ 2018/Jambi/SPKT"C" ialah disebabkan oleh adanya laporan yang dicabut oleh korban bagi pelaku.

Adanya korban yang mencabut laporan merupakan bagian rangkaian dari upaya lanjutan dalam prose penyelesaian nonpenal atau penyelesaian secara kekeluargaan yang sudah dilaksanakan oleh Pihak Keluarga sipelaku pada korban, yang mana keduanya bersepakat telah membuat surat perjanjian perdamaian diantara kedua belah pihak.

Didalam surat tersebut dituangkan adanya pokok perjanjian sebagaimana intinya adalah :

"Sehubungan adanya terjadi tindakan perkosaan dan hubungan badan yang diperbuat oleh pelaku pada korban, maka dengan penyelesaian melalui kekeluargaan dan sudah diselesaikan oleh pihak korban dan pihak pelaku. Keduanya bersepakat demi melaksanakan perjanjian damai mengenai perbuatan sebagaimana disebutkan diatas, dan yang sudah dilaporkan oleh korban didalam laporan polisi : B.210/VIII/2018/Jambi/SPKT"C". yakni:

Adanya upaya damai diantara korban dan pelaku dilakukan dengan berdasarkan kesepakatan-kesepakatan

1. Sudah tercapai kata sepakat diantara Pihak Pertama (Pelaku) dan Pihak Kedua ( Korban);

2. Pihak pelaku sudah melakukan upaya damai dengan Pihak korban dengan dilangsungkannya proses nikah dan pertanggungjawaban atas perbuatan yang telah dilakukan oleh Pelaku pada korban;

3. Pihak Pelaku akan mempertanggungjawabkan kandungan Pihak korban dan Pelaku bersepakat korban tidak akan ditinggalkan dan sudah merupakan suami isteri secara sah.

Didasarkan pada kesepakatan damai diantara pelaku dan sikorban, maka korban mengajukan permohonan untuk mencabut laporan polisi.

Didalam permohonan yang diajukan oleh korban, disebutkan isinya menyatakan sebagaimana berikut :

1. Korban tidak ingin memproses lebih lanjut kasus tindak pidana pemerkosaan sudah dilaporkan olehnya secara hukum;

2. Sesudah Surat Permohonan ini ditanda tangani oleh korban, maka kasus ini dianggap sudah diselesaikan dan korbabn tidak melakukan pelaporan atau penuntutan lagi dikemudian hari pada Pihak kepolisian,

3. Jika Korban melanggar isi surat pernyataan ini, maka korban bersedia untuk dilakukan penuntutan sesuai dengan aturan hukum atau undang-undang berlaku.

Didasarkan pada hasil proses lidik dan sidik yang sudah dilakukan oleh pihak Kepolisian, dan disebabkan permohonan pencabutan laporan yang diajukan oleh korban, dan lampiran perdamaian kedua belah pihak, maka Pimpinan Penyidik megeluarkan Surat Perintah Penghentian Penyelidikan dengan pokok No: SPPP/485.4/X/Res.1.24/2018/Ditreskrimum. Didalam surat tersebut, Penyidik Ditreskrimum Polda Jambi mengintruksikan pada penyidik bertugas memproses perkara Pemerkosaan anak untuk :

1. Mengambil tindakan menghentikan proses lidik dan sidik pada diri sipelaku;

2. Surat tersebut dinyatakan mula diberlakukan sejak diterbitkan oleh penyidik;

3. Sesudah melakukan surat perintah tersebut, untuk selanjutnya supaya dibuatkan Surat Berita Acara Penghentian Penyelidikan dan Penyidikan.

Upaya lanjutan, maka Direktur Reskrimum Polda Jambi menyatakan dikeluarkannya kembali surat ketetapan no: S.Tap/ 405.B/X/2018 Reskrim tentang Penghentian Penyelidikan, dengan ketetapan :

1. penyelidikan dan penyidikan perkara pemerkosaan anak dilaporkan oleh korban dihentikan;

2. Penghentian penyelidikan diberitahukan pada Pelaku;

3. Surat Ketetapan Penghentian Penyelidikan ini mulai diberlakukan pada tanggal ditetapkan.

Didasarkan pada fenomena hukum yang telah diuraikan tersebut, maka menurut Pendapat penulis, adanya alasan didalam menghentikan proses penyidkan pada perkara tindak pidana pemerkosaan anak didalam laporan polisi No : B.210/VIII/ 2018/Jambi/SPKT"C" yakni :

1. Dilampirkannya surat perjanjian damai yang dilaksanakan pelaku dan korban,

2. Pelaku menyatakan sedia untuk mengeluarkan segala macam kerugian yang dialami oleh korban dengan adanya suatu pengharapan ;

3. Korban mau mencabut laporan dengan diajukannya surat permohonan pada penyidik; 
4. Korban tak mau lagi memproses kaus pidana pemerkosaan yang dialaminya dengan alasan sudah melaksanakan pernikahan dengan pelaku dan bersepakat melakukan perdamaian.

Berdasarkan hal itu, menurut Penulis didalam perkara pidana tidak semua perkara yang dilanjutkan sampai pada kejaksaan untuk dilakukan proses penuntutan atau hingga pada persidangan dipengadilan, akantetapi terdapat adanya alasan-alasan yang kadang diharuskan suatu perkara pidana untuk dihentikannya penyidikan atas dasar perintah penyidik, sebagaimana telah diuraikan dalam perintah penyidik seperti diatas, untuk itu proses hukuman didalam hal ini penyidikan kasus pada seorang pelaku diharuskan berhenti.

Didalam perkara pidana perkosaan anak, menurut Pendapat Penulis walaupun kasus ini bisa berhenti didalam proses sidik, tetapi dalam hakekatnya tak bisa untuk mengembalikan kondisi badan serta jiwa diri perempuan seperti dahulu sebelum terjadi kasus tindak perkosaan. Hal tersebut disebabkan, didalam kasus pemerkosaan perempuan sebagai korbanlah yang menanggung semua akibat buruk yang muncul oleh karena kasus pidana perkosaan yang dialami. Tidak segala perkara pidana perkosaan yang mana pelakunya ingin mempertanggungjawabkan perbuatannyan yang mengakibatkan korban hamil. Sudah tentu adanya keharusan untuk bertanggungjawab pada korban pemerrkosaan dan memberi nafkah lahir dan batin.

\section{SIMPULAN}

Didasarkan apa yang sudah diuraikan tersebut, Untuk itu dapat disimpulkan beberapa hal seperti:

1. Proses penanganan kasus pidana perkosaan anak oleh penyidik didalam laporan polisi No : B.210/VIII /2018/ Jambi/ SPKT"C" dilaksanakan dengan membuat laporan Polisi yang dilaksanakan korban di Sentra Pelayanan Kepolisian Terpadu Ditreskrimum Polda Jambi. Setelah itu pimpinan Penyidik mengeluarkan surat perintah tugas diberikan pada penyidik dan penyidik pembantu yang menanggulangi perkara yang tindak pidana hingga proses keluaranya Surat Perintah Penyelidikan didalam perkara pidana perkosaan anak. Selanjutnya dilakukan proses riksa pada saksi-saksi serta dikumpulkannya bukti terkait perkara pidana, perkosaan anak, hingga penyidik memiliki kesimpulan bahwa benar sudah terjadi peristiwa pidana perkosaan pada anak dibawa. Akan tetapi dalam kasus yang penulis teliti, ternyata dihentikan, proses penyidikannya dikarenakan ada laporan polisi yang dicabut oleh pelapor.

2. Terdapat adanya alasan didalam Proses penyidikan yang dihentikan oleh penyidik pada perkara pemerkosaan anak sebagaimana tertuang didalam laporan polisi No : B.210/ VIII/ 2018/ Jambi/ SPKT"C" yaitu karena korban yang mencabut laporan. Tindakan ini dilakukan oleh korban disebabkan diantara Pelapor dan Terlapor sudahh bersepakat untuk melaksanakan damai dan Terlapor mau bertanggungjawab atas diri korban yang sedang hamil dengan cara menikahinya serta menjadi suami yang bertanggungjawab bagi Pelapor.

\section{Saran}

1. Didalam kasus perkara pemerkosaan, mayoritas yang jadi korban merupakan wanita baik dewasa maupun anakanak. Hal ini menunjukan perlunya perlindungan hukum bagi perempuan dan anak-anak dibawah umur agar tidak menjadi korban dari pelaku yang tidak bertanggungjawab, khusus dengan meningkatkan peran serta dan perhatian orangtua terhadap anak-anaknya untuk melaksanakan pengawasan supaya tidak terjadi peristiwa yang tidak diingin.

2. Didalam menangani perkara pidana pemerkosaan pada anak dibawah umur, maka sudah selayaknya penyidik memperhatikan hak-hak korban maupun hak-hak si tersangka, sehingga dapat dihindari adanya penyimpangan prosedural yang tidak sesuai dengan aturan hukum yang seharusnya.

\section{DAFTAR PUSTAKA}

Andi Hamzah dan Irdan Dahlan, Perbandingan KUHP dengan HIR dan Komentarnya, Ghalia Indonesia : Jakarta, 2009.

C. Djisman Samosir, Segenggam Tentang Hukum Acara Pidana, Nuasan Aulia.Bandung.2013.

Husein Harun, M. 2001. Penyidikan dan Penuntutan Dalam Proses Pidana, Rineka Cipta Jakarta.

J. Supranto, Metode Penelitian Hukum dan Statistik, cet. Ke-1, (Jakarta:Rineka Cipta, 2003).

Lilik Mulyadi, 2007. Hukum Acara Pidana Normatif, Teoritis, Praktik dan Permasalahannya, PT.Alumni. Bandung. Momo Kelana, Konsep-konsep Hukum Kepolisian Indonesia, Jakarta: PTIK Press, 2007.

M. Yahya Harahap, Pembahasan, Permasalahan dan Penerapan KUHAP, Garuda Metropolitan Press : Jakarta, 2006.

R. Soesilo, Hukum Acara Pidana (Prosedur Penyelesaian Perkara Pidana Menurut KUHAP bagi Penegak Hukum), Politea : Bogor, 2005.

Undang-Undang Nomor 8 tahun 1981 tentang Kitab Undang-undang Hukum Acara Pidana (KUHAP)

Undang-Undang Republik Indonesia Nomor 2 Tahun 2002 Tentang Kepolisian Negara Republik Indonesia. 
M. Rudi Hartono dan Lilis Winantri, Analisis Laporan Kepolisian No: B.210 /VIII/2018/JAMBI/SPKT.C Mengenai Alasan Dihentikannya Penyidikan Perkara Perkosaan Anak

Undang-Undang Republik Indionesia Nomor 35 Tahun 2014 Tentang Perubahan Atas Undang-Undang Nomor 23 Tahun 2002 Tentang Perlindungan Anak. 